\title{
Retrieving the Exiled Reference: Fred Vargas's Fetishization of Ancient Legend
}

\author{
Alistair Rolls \\ University of Newcastle, Australia
}

This article offers an analysis of the writerly reading praxis of Fred Vargas's favourite, or fetish, detective, Jean-Baptiste Adamsberg. This praxis will also be shown to be that of a fetishistic detective, whose modus operandi we compare to the critical stance of the $f l$ âneur of Charles Baudelaire's nineteenth-century prose poems. The response of the poet of Les Petits poèmes en prose will be revealed to be that of Freud's fetishist, a mediation of traumatic present and a reconfigured, mythological past. In L'Homme à l'envers (1999) Vargas's detective will be shown to engage actively with the murder text, his writerly reading ultimately making him co-author of the crime alongside the murderer. This textual performativity will be paralleled to the engagement with modernity that is the very substance of prose poetry; and what Nikki Santilli terms the 'exiled reference', the abstract stuff of verse poetry, will be shown to be simultaneously opposed to and always already repatriated into its existential counterpart.

For Ross Chambers, the trace of the past is indelibly inscribed in the modern metropolis. Indeed, the shadow cast over the present is so marked that he talks of it in terms of a 'haunting'. Chambers's past is a lived one, or at the very least a remembered one; it is a past that accompanies us. Rather than gradually fading into distant memory, its interaction with living sites integrates it into the realm of the legendary, a space no longer authored by ancient protagonists but produced as text by contemporary readers. The urban experience is likened in Chambers's model to critical reading: it is a way of adopting what he refers to as a 'belated stance' in relation to the world, a stance that is always simultaneously at one remove from that world and immediately present to it. And when James Donald says of Paris that we come to it 'through texts' and that '[it] also comes to us as already a text', it is easy to transpose onto this complex network of streets and cafés the figure of the detective working his way through clues in order to discover a truth that is there but which has been obscured by the sheer abundance of material and the speed with which it unfurls before his eyes. This is, however, to overlook the performativity of the city as text that is expounded by Baudelaire's prose poems, according to which the street is text not to be read but to be produced by the 
poet as he moves through it. In Les Petits poèmes en prose poetic tropes, such as Goddesses and Love, signify the objective approach of the poet-detective turning mundane truths into abstract Truth whilst, in the very same streets/sentences, the littleness of the world and the sharpness of modern infinity indicate the way that reality eludes such abstraction. The beautiful thus remains real, 'haunted by' but not the same as the Beauty that the poet once sought.

The city as prose poem is an oxymoron, a place of narrative tension where the city as work (or objectively considered system of Meaning) vies with the text as site of production, streets to be read critically even as they are trodden. This is what Chambers means by being slightly out of step with the world: the flâneur is both in and outside his time. Unlike the voyeur reading the street from the objectivity of the café window, the flâneur is in constant motion, both objectively reading and subjectively acting in the modern world. It is this motion that makes him a contradiction in terms and a metaphor for modernity itself. The modernist text becomes a place of alienation and productivity, pulling the reader in (Satanically, to use Baudelaire's terms) by the very way that it repels him or her with its self-referential ploys (forcing engagement by distancing the reader from the story). The urban text becomes, then, a writerly text. And for Roland Barthes, too, this tendency not to see the new in everything but to reinvent it within the old by forging the writerly (and spurning the mass-produced forms of the readerly) is a way of reading depth into the city, of decoding it as a vast metaphor.

Jean-Baptiste Adamsberg, the hero of Fred Vargas's detective stories, has a modus operandi that is similarly out of step; rather than viewing the case from the objective perspective of the impartial reader of evidence, he allows his thoughts to run off at tangents, following the movements of the case (as it were, in real time) and other trajectories that are stories sprung from his own creativity. In this way Adamsberg will endeavour to solve the case by repeated attempts to abstract himself from the world around him. There will thus be no simple synthesis of past (reading crime cases) and present (application of deductive principles in order to apprehend the criminal); instead, there will be a constant mediation between the existential present and a mythical past. In other words, he will read the present and the past in parallel, solving the crime by treating it critically, that is to say reading its meaning in the sense of producing the outcome (for not only are legends shown to be generated from the perspective of the present, but Adamsberg also decodes this tendency to exploit the past by wrestling the responsibility of authorship of the present text, in a very real sense, from the murderer). 
In this way, Adamsberg reads the modern city or crime scene like a flâneur, forever moving between the poles of the voyeur and the man in the crowd.

To the extent that he negotiates a path through an unpalatable present via a rewriting of the past, the flâneur operates fetishistically. For, like the fetishist who cannot endure the revelation of the truth, the flâneur sees in the haunting of the present city by the old a way of reconstructing a parallel mythology that, by co-existing rather than fusing with it (and thus replacing it in synthesis), will temper the reality of the modern world. To discuss the flâneur in terms of fetishism is to see in his behaviour a cleavage of his two opposing modes (objective voyeurism and subjective action) much as Freud saw a cleavage of the ego faced with the truth of negative outcomes resulting from the satisfaction of a pleasurable instinct. The resultant split draws on the dual meanings of the auto-antonym, 'to cleave'; that is to say that the two pulls are, for ego and flâneur alike, both divided and joined, a condition that Freud himself deems paradoxical. Elizabeth Rottenberg emphasizes that Freud is 'radically shifting the notion of splitting', noting how '[i]n order to avoid a break, the ego must divide itself. In order not to lose itself, the ego must agree to lose its integrity'. 'Critical opinion, too, is similarly cleaved: where J.-B. Pontalis sees in the development of the fetish 'la discordance entre le savoir et la croyance', Ellen Lee McCallum speaks of the 'unique intersection of desire and knowledge'. ${ }^{6}$ A haunting of the present is, in the same way, a way of continually juxtaposing, overlaying, and opposing two entities that are, to all intents and purposes, mutually exclusive.

Successful operation within the parameters of the present requires, on the part of flâneur, fetishist and detective alike, a writerly (re/de)construction of the past. In Vargas's novel, Adamsberg's innovation lies in the way he makes his mythology tangible in the present by writing the ongoing murder script, a detective process based on a critical reading praxis made creative writing project.

Baudelaire's prose poems effect a similarly fetishistic procedure in the way they produce mythological elements alongside mundane objects of existence in their street scenes. Existence is juxtaposed with essence rather than simply appealing to it. Clearly, existents are haunted by essences inasmuch as their forms may be said to appeal to abstract blue-prints of particular thing-ness; in the prose poems things that are beautiful (by virtue of that way in which we understand them via the abstract concept of Beauty) are placed alongside, without being eclipsed by, Venus herself. This way of 'appealing 
to' is always already countered, however, by a breakdown in the process, which shows the inability of man to commune with God even, and perhaps especially or more pointedly, when $\mathrm{He}$ is materially present in the same street. Nikki Santilli describes this appeal to a necessary but impossible (and always absent) Other as a particular form of haunting: 'the ideal prose poem is not hermetic, despite its appearance, because it relies on the dialogue between itself and its context (the exiled reference)'. ${ }^{7}$ Through this intentionality, this tendency to push forever beyond its own present frame of reference, the prose poem is no more 'ideal' than it is hermetic; its meaning is a performativity based on the continual clashing of existents and de-abstracted essences. Whilst the jagged edges of Baudelaire's continuum prevent synthesis of opposites, it seems that Santilli's 'exiled reference' is always already repatriated in Baudelairean prose poetics. And in Fred Vargas's detective novels the legendary past is simultaneously exposed as myth and made real. Legend is, in other words, always brought out of its exile, read critically, and made existentially present.

We shall concentrate here on the mechanics of this repatriation of legend in Vargas's L'Homme à l'envers (1999), a tale in which the myth of the werewolf resurfaces in the modern world. In order for this to be debunked as a myth, ancient lore must come alive and be dealt with on its own terms. And, in particular, our focus will be on the primal scene that is exploited by the killer, and on which the tension of the novel is predicated. For the novel is deeply (and superficially) fetishistic in its negotiation of mythical space.

In L'Homme à l'envers Adamsberg first interfaces with the legendary via his television screen: a news broadcast functions as a mediating space between the Paris-based detective and his soulmate Camille. The virtual realm is his gateway between the modern metropolis and the eternal space of Le Mercantour, in which sporadic but increasingly frequent killings of lambs are reviving age-old myths. The exiled reference resurfacing in the French provinces is that of the primitive man who haunts the modern rationalist, appearing as shadowy movement seen out of the corner of the eye in that twilight period that the French refer to as 'entre chien et loup'. The question on national news broadcasts is whether these attacks are the work of wolves that have travelled across the border from Italy or whether they are the work of one lone wolf. Framed in Deleuzian terms, it is a question of 'un seul ou plusieurs loups'. In their essay of that name, Gilles Deleuze and Félix Guattari criticize Freud's use of the singular in his analysis, suggesting instead that the Wolf Man is prey to a multiplicity, a horde, and not to the repressed material of one locatable past event. (This argument, they suggest, is 
even present in Freud's own account, according to which there are a number of wolves in the tree watching the boy in his dream.) The tendency, which Deleuze and Guattari label the 'becoming-wolf', is thus for ideas of singularity to mask multiplicities. The relevance of this critique of Freud's essay is reinforced by the exploitation in Vargas's novel of the inverted reading that Freud himself employs in explaining the repressed childhood material in the case of the Wolf Man, according to which a scene of marked passivity symbolizes and represses a primal scene of intense activity. In order to establish a workable truth in the case of Vargas's homme au loup, it will be necessary to embrace certain keys to Freud's homme aux loups and thus adopt a process of reversal. And indeed, such Wolf-Man-style analysis suggests early on in the piece that the primitive hordes of wolves do in fact mask a single wolf. Moreover, this tendency towards multiplicity, the call of arcane mysteries, is the becoming-wolf of one man.

When the extraordinary emerges from the mundane present of Adamsberg's Paris, it is diffused, made multiplicity, across the signals and receptors that lead to the mediated screening of the television. The mysterious quality of the exiled reference brought to life by the broadcast is showcased by the blandness of Adamsberg's supper of pasta and cheese. Two words stand out both for Adamsberg and the reader: 'Réalité ou légende?' (p. 13). Adamsberg is careful not to disturb the news-reader; having ensured that the broadcast should not be upstaged by his cuisine, he treads carefully around his room: 'Un geste de trop et ce type s'enfuirait de la télé, sans finir la formidable histoire de loups qu'il venait de commencer' (p. 13). Hindsight reveals just how polysemous this taking of care is: should either Vargas or Adamsberg dispel the myth of the wolf legend too early, then the reader's interest would be lost at this early stage, the plot of the detective story shattered in its very construction; should the reader crack the case, then the same would, of course, apply; and lastly, were the criminal to be disturbed in the construction of his myth - for it is the killer who is weaving the tale of the wolf man by rekindling primeval fears - then the novel would again be lost. And if Vargas can afford such $\mathrm{fl}$ agrant self-referential devices, it is because her readers are familiar with Adamsberg's approach. They know him as a master reader of text; they know, too, that he will read along with them, producing the text at the very rhythm that it is consumed. This device has an impact that belies its apparent attempt to defy the reader to curtail his or her own reading pleasure: the reader derives that pleasure not from clue-cracking but from readerly leisure, in full knowledge that the blissful, writerly reading will be effected by the investigating protagonist.

Adamsberg will write the text of the murders in parallel with the murderer, acting as 
critical, writerly reader to the latter's author. The parallel is made through the love-hate relationship that defines Adamsberg's relationship to wolves: 'Adamsberg aimait les loups comme on aime ses cauchemars' (p. 13). Despite the heavily intertextual and Deleuzian tendency of the text to tap into ancient lore and the oral tradition of wolf 10

tales, Vargas's novel clearly signposts the importance of dream analysis. So, whilst the murder text taps into tales of the collective unconscious, drawing on fears of werewolves, our investigator will need to look into his own, personal fears in order to find the murderer:

[Et] quand il parcourait la montagne à la nuit, à neuf ans [. . . ] il croyait voir leurs yeux jaunes le suivre tout au long des sentiers. Comme des tisons, mon gars, comme des tisons ça fait, les yeux du loup, la nuit. (pp. 13-14 - original emphasis) This extract demonstrates how echoes of the voice of the father stain this novel from the outset. In Adamsberg's childhood this primal fear of the wolf had to be overcome so that the man at its origin could be unveiled. And this, too, requires Freud's art of reading in reverse. Adamsberg's animosity towards his father, whose demands that the young boy collect kindling in the dark have indelibly marked his psyche, must be reconfigured and translated onto the murderer as the desire not to enact revenge upon the patriarch but, instead, to avenge him. For the murderer will forge his path on the love of a despicable man in the same way that so much of what we know as 'human behaviour' is built on irrational fears: 'Comme quoi c'est désespérant, l'être humain, ça s'attache à ce qu'il a de pire' (p. 14).

Adamsberg's memories of his father are of the latter's terrifying description of the wolf, which has become a source of morbid fascination in Adamsberg the adult. In this way, the novel contains the essence of its intrigue in its opening pages; and its gentle, selfreferential warning to tread carefully lest the story be passed over unnoticed also contains a suggestion that a loiterly reading of Adamsberg's first — primal — chapter can reveal the key to the mystery: the murderer will be seeking to avenge his father, not to overthrow him; and his love for his father will not be a love for what is best in his life, but for the worst. The killer will spurn and feign love for those apparently dearest to him, at the same time as nurturing his love for an evil father. This is the seed sown in Adamsberg's mind, and which will light his way through the plot like wolves' eyes in the dark.

Adamsberg thus comes quickly to doubt that the savage acts terrorizing Le Mercantour can be the work of noble beasts that have come from across the Alps. In fact, they will 
turn out to be those of a noble man who has come from across the Atlantic. ${ }^{11}$ The adult storyline that grows out of this primal introduction, is referred to as a roade-mouvie, in other words it is a transvalorization of an all-American classic: Camille and Soliman (the son of a victim, thus bent on revenge in the same way as the murderer), accompanied by the shepherd le Veilleux who represents the pathway to the exiled reference of the legendary, pursue the murderer as the text unfurls along provincial highways. Yet, although hybridity and border crossing are at a premium - the murderer will turn out to be as American as the claw he uses, which does not even come from a European wolf - the critical reading strategy used to crack the case draws on an established pattern that is typically Vargas.

With the benefit of hindsight it is clear that Vargas signals the identity of the killer in the clearest possible terms. Adamsberg's reflections on the legendary fi gure of the lone wolf close one chapter, only for the next to begin with the name of the killer, whose description is surprisingly lupine: 'Un solitaire roué, cruel, s'approchant des villages à la nuit, avec son cul bas sur ses pattes grises. [. . .] Lawrence Donald Johnstone ne redescendit au village que le vendredi, vers onze heures du soir' (pp. 16-17). It is thus Lawrence who becomes the werewolf, the inverted or inside-out man, by virtue of the relationship he maintains with his dead father. By remembering his instructions, and chanting them like a mantra similar to that which throws Adamsberg onto his scent, Lawrence immortalizes him, nurturing his legend via the wolves and particularly through his veneration of the old wolf Augustus, which he anthropomorphizes: 'Il restait muet, suivant en cela le précepte de son père: «Si tu veux rester libre, ferme ta gueule.» [ . . . Le vieillard était passé et le vieillard avait mangé' (p. 20). The tale becomes a series of sacrifices made to the father and as a result of which the father can be kept alive. As Camille says, Augustus is not 'un homme fini' (p. 21). Adamsberg must perform the inverted reading of Lawrence's parallel (and opposite) trajectory, i.e. his becoming-wolf. While Augustus's longevity is symptomatic of the motive for the murders, the concept of embracing the darker side of humanity and keeping alive childhood nightmares is symptomatic of Vargas's novels as a whole. As Sara Poole comments, ‘Fred Vargas conceives of the polar as a modern vehicle of mythologies'. ${ }^{12}$ And yet, as elsewhere in Vargas's œuvre, L'Homme à l'envers deploys a multi-layered system of mediation to retrieve the exiled reference and render it present.

Camille, whose boots interconnect the Adamsberg novels and serve to draw the belated detective into this particular text, arguably symbolizes this mediation to an even greater 
degree than Adamsberg. Not only does she operate across time-zones, seemingly linked to Adamsberg in the past, present, and future, but she also acts as the link between the detective and the murderer, both of whom she knows as lovers.

For his part, Lawrence looks on Camille with a lover's gaze. This gaze is also poetic in its distancing from the represented object. Camille's beauty for him is a function of her withdrawal from everyday life. This is true for Adamsberg, too, although to a lesser (mediated) degree. For Adamsberg, the infinite timeline that is his love for Camille needs to be punctuated; he must see her from time to time, to add the reality of presentation to the perfection of the tableau. Note the controlling power in Lawrence's representation: 'Camille n'était jamais si belle que lorsqu'elle se concentrait, pour le travail ou pour l'amour. Lawrence posa son sac, s'assit à la table et l'observa pendant quelques minutes' (p. 21). ${ }^{13}$ The equal weighting of mundane love and the verse motif, love, adds a prose-poetic touch to the subject matter of what remains a predominantly withdrawn, voyeuristic (and thus poetic) passage.

This quasi-authorial command will, of course, turn out to be the hallmark of the murderous writing praxis (as opposed to the critical reading approach of the deconstructive detective). Everything about Lawrence's character speaks of deliberate (and duplicitous) construction. His conversation, for example, is a metonym for his character; it lacks an overarching meaning system in the same way that Baudelaire's prose poems lack the framing effect of an aerial view of Paris, dropping the reader into the middle of the city (for whose present reality they thereby come to stand metonymically and metaphorically). Inasmuch as it embodies both the poetry and prose of the prose poem, the silence that Camille encounters in Lawrence is unlike that which draws the motley fool to Venus; their meeting is a compromise, a communication based on partial silence. He has trouble beginning or ending sentences, so those who speak to Lawrence are always already in mid-sentence, at the heart of the action. Perversely therefore, it is his apparent desire to avoid the world of human contact that sees him, linguistically speaking, stranded in its very heart. This oscillation between realms is a noir characteristic compatible with and derived from his status as murderer. And if Camille and he can communicate, it is because they are not opposed like Venus and the motley fool, but because each of them encapsulates the dynamics of that opposition.

This noir tension is what drives Lawrence; it is this paternal legacy that makes him, like his wolves, a real 'tough guy' (p. 27). Were it not for this, he would retreat to the edge of his frame and compose the drama of his relationship with Camille: 'Pourquoi s'emmerder 
avec ce foutu loup quand il pouvait rester sa vie entière dans cette pièce avec Camille' (p. 27). His fate as murderer is also sculpted in plotlines that are common to other Vargas novels. There are, for example, clear structural similarities between L'Homme à l'envers and Dans les bois éternels. The murderer in the latter is the pathologist, Dr Ariane Lagarde, who performs autopsies after her own crimes. ${ }^{14}$ In L'Homme à l'envers Lawrence combines the roles of Adamsberg and Lagarde in Dans les bois éternels: he is grudgingly accepted into the closed circle of a French provincial community and performs autopsies on the mutilated sheep. As does Ariane Lagarde (who promotes the theory of an elderly female killer), he distracts attention away from himself by designating, perversely, a killer that corresponds to a description of himself: 'Beau mâle' (p. 29).

With a combination of self-referentiality and purloined-letter-style devices, Vargas has by this stage of the novel ensured that Lawrence's guilt has been symbolized and made clearly readable. In order for both sides of the fetishistic framework to be in place, the symbol of truth must be paralleled by its veiling. Vargas duly provides a scene in which a fetish is established, one that will allow Camille to follow the case clue by clue whilst still maintaining her faith in the virtue and phallic heroism of the rugged Canadian zoologist.

Camille is escorted to the new crime scene by Lawrence and is called upon to look on the remains. The body is not, however, what is expected: the victim is not a lamb this time, but her friend Suzanne. Although the policeman guarding the scene invites them to look at the corpse, he frames his invitation within a prohibition: they are told not to touch anything. This, of course, has the logical but paradoxical result of increasing the naturally morbid fascination of the voyeur/reader: 'Faut toucher à rien, dit-il d'une voix mécanique. Faut toucher à rien. En même temps, il leur fi t signe d'une main fatiguée qu'ils pouvaient $y$ aller' (p. 78). There is, therefore, a fatality about the policeman's warning. This allows Lawrence to coax Camille towards the scene, both adhering to and contravening the law. The scene that follows will traumatize her whilst allowing him to be seen to be acting in her defence.

Elle tourna le regard vers la bergerie [ . . ] Lawrence l'avait déjà précédée quand elle pénétra dans la bergerie. II se retourna vers elle, blanc comme un drap dans l'ombre, étendant ses deux bras pour l'empêcher d'aller plus loin.

- Avance pas, Camille, souffla-t-il. C'est pas une brebis. Jésus Christ. (p. 79) In film-noir style, Lawrence cuts a white figure against the black backdrop of the barn, projecting himself onto the scene in biblical terms. But neither he nor the victim is the Lamb of God. And yet, as he raises his arms in the sign of the crucifi x, uttering as he 
does so the name of Christ, he manages to veil himself in innocence, to such an extent that both Camille and the reader have their eyes fixed in anticipation on the scene to come and not on the words used to introduce the scene: 'Lawrence l'avait déjà précédée quand elle pénétra dans la bergerie'. He has been there before Camille for the simple reason that he is the killer.

It is clear then that Camille, like the reader, has seen the truth; both have read the signs and made the appropriate connections, albeit unconsciously: 'Mais Camille avait vu' ( $p$. 79). The trauma that is now set in place will allow her to maintain simultaneously her unconscious realization of Lawrence's guilt and her belief in his innocence:

Mais Camille avait vu. Suzanne était étendue dans la paille crottée, sur le dos, les bras écartés, la chemise de nuit remontée jusqu'aux genoux. À la gorge, une horrible blessure avait laissé échapper un flot de sang. Camille ferma les yeux et sortit en courant. Elle se heurta au gendarme moyen, qui la retint dans ses bras. (p. 79)

Suzanne, too, is placed in a Christ-like pose with her lifted nightgown hinting at the upward glance that was famously at the origin of Freud's account of the fetish. Perversely and yet appropriately, it is the law man who, by seeking to protect Camille from her own trauma, reinforces her escape into fetishism. By seemingly preventing her from running from the truth, he ensures that she does just that: '«Qu'est-ce qui s'est passé?» hurla-t-elle. «Le loup, dit le gendarme. Le loup»' (p. 79). Thus the truth is masked by an inviting myth: that of the legendary and primeval wolf.

The policeman continues to strengthen the formation of the fetish by encouraging Camille to repress her pain, to seek solace in the unconscious: 'Moi aussi j'ai de la peine, dit le gendarme. Mais faut pas le dire. C'est pas réglementaire' (p. 79). His attitude as the scene develops is less clear-cut, however. He reinforces her position as the child in the classic Freudian scenario, by calling her 'ma petite', only to order her not to behave as one: 'Allons, faites pas l'enfant, faites pas l'enfant' (p. 80). But clear-cut is not the way of the fetish, which encourages one mode of behaviour (escapism and denial) whilst maintaining its opposite (knowledge of the truth). Thus, when Camille begins to seek easy solutions, accusing the shepherd of failing in his duties, the policeman tells her that this is childish, warning her against 'âneries de ce genre' (p. 80). And of course, by this stage, she is fully primed to believe the biggest fairy-tale of them all: that of an innocent Lawrence and a madman killing with a wolf.

Clearly, this fetishization of Camille's gaze is a self-reflexive spin on the essential tenets 
of the detective story. Vargas puts a perfectly (prose poetically) balanced reader into the text to mimic our inability to see the truth (or our ability to suspend our belief in the truth): she will be both actor and observer in the text, both possessor and refuter of the truth. As we have shown, Camille sees the truth of Lawrence's guilt unconsciously. On the conscious level, she will deny this knowledge to the end, as shown by the statement she makes to Adamsberg on learning of Lawrence's arrest and confession: 'Je ne comprends pas, dit Camille dans un murmure. Je n'ai rien vu, rien senti' (p. 358).

As Adamsberg explains in his reply to Camille, Lawrence, too, is, a man of two sides. His whole worldview, from within which he consciously adopts a double role, is itself founded on a psychosis. Indeed, the primal scene that Lawrence stages in order to cause Camille to perceive the truth through the noir lens of the fetish is itself a replica of that which he was forced to endure as a boy. His own primal scene, the one that we readers do not discover until the resolution of the novel, involves his American father, John Neil Padwell, who killed his wife's lover before his son's eyes: 'Quand le père a tué Simon Hellouin, le gosse avait dix ans. Il a vu le meurtre. Après quoi, le petit Stuart était fichu' (p. 351).

The condition that the young Stuart Donald Padwell develops is, as Adamsberg explains, a psychosis, which is just what the adult Stuart, posing as Lawrence, sets up in the mindsets of the people of Le Mercantour: 'll a créé une psychose autour d'un Massart lycanthrope et sanguinaire' (p. 352). His killings avenge a father whom, as a result of his psychosis, he considers an innocent victim. The mood in which he can best exact his revenge is, therefore, a noir one, that is to say one in which all his fellow actors see, and believe in, a lie in place of the truth. As Pierre Bayard explains, there are two principal types of psychosis: there is that which causes the psychotic to believe a lie that is so preposterous that nobody else could possibly believe it (paranoid delirium); and there is the more insidious and therefore more dangerous type, which causes the psychotic to believe a lie that is defensible and convincing enough to pass as truth in the eyes of everybody else (paranoic delirium). ${ }^{16}$ Vargas's skill in L'Homme à l'envers is to move the reader from the first type to the second.

The natural disposition of the detective-fiction reader is arguably that of a willing psychotic - our inclination is to get to the end of the novel before discovering the truth (and thus to aid and abet the author), a desire that we often mask beneath feigned attempts to solve the clue puzzle. Thus, the reader observes as the fi rst people to hear 
the story of the werewolf treat it with scorn. We empathize with the principal characters, urging their interlocutors to buy into a tale that we should otherwise deride. According to our desire, the psychosis spreads until everyone believes the legend of the werewolf. The exiled reference, which nobody usually believes (although it is always there, haunting our steps in the modern city), is at last visibly present and overshadowing its modern (real) counterpart. And so, the fetishism that is deliberately forced on Camille has enveloped the whole novel.

Given the nature of Lawrence's psychosis, which is such that he operates entirely at a conscious level (merely with a psychotically skewed opinion of his father's guilt), the respective roles of the detective and the murderer in the reading and writing of the murder text are ostensibly clear. All Adamsberg has to do, it would appear, is wait for his unconscious vision of the truth to emerge in the conscious realm of his analysis of the evidence. This is not, however, the way of Vargas's novels. The following head-to-head between the two can be read as a joust for critical, or authorial, power:

— [Soliman] Massart tue au hasard, quand on le dérange.

— [Adamsberg] C'est bien possible. Mais je préférerais qu'on aille à Belcourt ce soir. Le bourg n'a pas l'air grand. S'il y a une croix plantée quelque part, on la trouvera, et on se postera là.

- Je n'y crois pas, dit Soliman.

— Moi si, dit soudain Lawrence. Pas certain, mais très possible ... $[\ldots]$

— Tu disais qu'il s'en prendrait aux femmes, dit Camille.

— [Lawrence] Me suis gouré. S'en prend aux femmes pour les consommer, s'en prend aux hommes pour se venger. Revient un peu au même. (p. 295)

Lawrence is drawn in here by Adamsberg; his admission that the detective's reading has validity is both mocking (inasmuch as it is 'wrong' in terms of Lawrence's conscious decision-making process) and praising (as it is a plausible explanation for what he has done, and may be 'right' at the unconscious level). The psychotic detective is seeking a superstitious killer. The killer, who considers himself to be anything but superstitious, is offered a view of himself that causes him to give himself away even as he believes that he is gaining the upper hand. In other words, when he diverges from the deliberately superstitious modus operandi that he has used until now, he is not simply making a blunder (which Adamsberg seems to suggest later to Soliman); nor does he throw Adamsberg off the scent. It is our suggestion that he in fact co-authors a complex murder 
text, incorporating Adamsberg's writerly reading into his enactment of his own plans. His admission of the killer's use of women for the purposes of exacting revenge on men explains his motives quite succinctly; it also appropriates the classic themes and psychology of the hard-boiled detective novel.

The scene where the detective and the murderer confront each other is furnished with the trappings of noir, which are typically ironic and self-referential in tone. Adamsberg begins the denouement by leaving the road, heading onto the narrow path between differently-sown fields. This departure marks a move away from the central thrust of the narrative, away from an evidentiary-based investigation towards an instinctive one. Adamsberg is battered and bruised, his weakened body throwing itself fatalistically upon a hunch:

Il avançait lentement, le bras droit coincé, la tête baissée vers les cailloux qui dessinaient une ligne blanche et sinueuse au sol. Il déboucha dans la plaine et s'orienta au clocher noir de Montdidier qu'on discernait au loin. C'était à peine s'il pouvait comprendre ce qui l'avait tant choqué ce soir. (p. 347)

The movement is still away from the whiteness of rationality towards the darkness of myth and primal forces. Despite not being able to understand what shocked him earlier in the evening, Adamsberg's movements are testament to his belief in a theory that has been forming in his unconscious for some time. As Vargas writes: 'Mais pourtant il avait vu' (p. 347). Just as Camille saw the truth earlier, Adamsberg has seen it too, with the result that 'tout ce qui grinçait dans l'histoire de l'homme au loup, comme des roues faussées, s'assouplissait devant cette hypothèse' (p. 347). For even until the last, this remains a hypothetical investigation, a reading of a text.

As with any persuasive reading, it carries all doubt before it. The tensions that drove the reader onwards - in this case the opposition of existential present and timeless legend - appear to achieve synthesis, becoming, to all intents and purposes, truth: 'Les angles s'estompaient pour ne former qu'une seule route, lisse, claire, évidente' (p. 347). And still, this is a truth that must be made, not that is; and Adamsberg has to force his intuitive reading to crystallize, to become transposed onto the existential plane: 'll s'arrêta, s'assit un long moment contre un arbre, explorant la solidité de ses pensées' ( $p$. 347). When he gets up from the base of the tree he throws off the psychosis of the wolf man and makes his way to the police station.

What happens next is, in narrative terms, inevitable, which is to say that Adamsberg and 
Lawrence both need it to happen. The confrontation takes place at an intersection: 'À miroute, à l'entrée du chemin qui séparait les deux champs, il s'arrêta net. À cinq ou six mètres, une silhouette noire, large et massive, un peu ramassée sur elle-même, lui barrait l'accès du sentier' (p. 348). Adamsberg's movement is back towards the main road of the detective novel; he is, as it were, integrating his digressive interpretation into the mainstream. His return to the existential realm of black and white will give the seal of offi cial approval to his tale. And yet, there have always been two authors, and any legitimization of the truth must be co-signed. In terms of the novel's principal dichotomy, legend and present must fuse together. Otherwise the revelation that the wolf was just a man would seem - and hence the importance of closing off the intersection - trivial. The legend of the werewolf must be negotiated, not repressed or, worse, treated and psychoanalyzed out of reality: 'La nuit n'était pas assez claire pour qu'il puisse distinguer les traits du visage. Mais Adamsberg sut sur l'instant qu'il faisait face au loup-garou. Le tueur vagabond [. . . ] se découvrait enfin pour un face à face meurtrier' (p. 348).

The noir twist to this tale recalls that of other Vargas novels. Adamsberg's victory lies in the intersection of his text with that of the murderer. There is no conquering of the authorial text, no upstaging of the murderer's genius. Here Adamsberg's pistol is empty; he is stripped of the phallus, and, even as the two men dispute the killer's 'true' identity, the day is saved by the young Soliman, the son of the first victim (thus providing a certain poetic justice for all three characters in relation to their parents' legacies). Synthesis of legend and reality is arguably realized in the staged killings and the official drawn result of the confrontation. By the same token, however, synthesis is forever held at bay, noired in an open-ended oscillation between two parallel stories, two realms whose truths are both incompatible and overlapping. This is resumed in Lawrence's acceptance of his arrest: his work is done; all his intended victims are dead. Whilst ostensibly an attempt to kill Adamsberg and prevent his interpretation from surfacing, the stand-off brought his murder text the closure of the critical reading, without which the legend would have faded out of credibility.

With her complex intertwining of authorial power and writerly reading, Fred Vargas thus achieves a noiring of truth, in which ancient legends are at once debunked and legitimized in the critical space of the modern world. And in this way, her self-styled rompols, with their exploitation of collective psychoses and fetishistic rewriting and historical localization of eternal legends, recreate, in detective-fiction format, the paradoxically fragmented infinity of Baudelaire's prose poems. 
Notes

1. Ross Chambers, Loiterature (Lincoln and London: University of Nebraska Press, 1999).

2. James Donald, Imagining the Modern City (Minneapolis: University of Minnesota Press, 1999), p. 44.

3. Michel Covin sees in the flâneur a figure constantly vacillating between the opposing gazes of the voyeur and the unquestioning badaud. See Michel Covin, L'Homme de la rue: Essai sur la poétique baudelairienne (Paris: L'Harmattan, 2000).

4. Following this idea, a reader who only sees in a text its face-value 'meaning' only ever reads through the lens of the present; the critical reader, who takes the time to reread, discovers new sides to the old. Taking the time to read the same text has the paradoxical effect, therefore, of preventing the reader from seeing the same text everywhere.

5. Elizabeth Rottenberg, Inheriting the Future: Legacies of Kant, Freud, and Flaubert (Stanford: Stanford University Press, 2005), p. 62.

6. J.-B. Pontalis, 'Présentation', Nouvelle Revue de Psychanalyse, 2 (1970), 5-15 (p. 11), published in book form as Objets du fétichisme (Paris: Gallimard, 1970); Ellen Lee McCallum, Object Lessons: How to do Things with Fetishism (New York: State University of New York Press, 1990), p. xii.

7. Nikki Santilli, Such Rare Citings: The Prose Poem in English Literature (Cranbury, NJ: Associated University Presses, 2002), p. 205.

8. Fred Vargas, L'Homme à l'envers (Paris: Viviane Hamy, 1999). The edition cited throughout this document is published by Magnard, 2001.

9. For Deleuze and Guattari man's devenir-loup is his tendency to become wolf. Gilles Deleuze and Félix Guattari, Capitalisme et Schizophrénie 2: Mille Plateaux (Paris: Les Éditions de Minuit, 1980), pp. 38-52.

10. The tendency of a text to point outside itself, into the intertext, via apocryphal tales of roaming packs of wolves is also manifest in Marie Darrieussecq's tale of multiplicity, Truismes (Paris: P.O.L., 1996), in which the 'becoming-pig' of a young woman tends towards her lover's 'becoming-wolf'.

11. Lawrence's background can be read as a comment on the trans-Atlantic origins of 
Marcel Duhamel's Série Noire which is born out of the translation in 1945 of three Anglo-Saxon hard-boiled thrillers and, as such, adumbrates the arrival in France the following year of the series of American films that give rise to the coining of the term 'noir' (which is itself then transported back across the Atlantic). In L'Homme à l'envers the killer, although American by birth, will be turned native; moving to France, via Canada, and only a deep-seated lust for vengeance will remain of his American ancestry.

12. Sara Poole, 'Rompols not of the Bailey: Fred Vargas and the polar as mini-protomythe', French Cultural Studies, 12 (2001), 95-108 (97).

13. We should emphasize that Lawrence's love for Camille is removed from the brutal reality of his murder text. Far from objectifying her, he renders her abstract, effectively exiling her from the world of existents. This distance will also make Camille, be it incidentally or as part of Lawrence's plan, the perfect vehicle for propagating the theory of l'homme au loup.

14. Fred Vargas, Dans les bois éternels (Paris: Viviane Hamy, 2006).

15. It should be noted in passing that the subsequent trajectory of Lawrence's mother, who is curiously also called Ariane, reflects the genesis of noir fiction in France. She travels from France to America with her American lover; she then marries him and settles down in her new homeland; she next has an affair with a Frenchman, before returning definitively with him, at which point her tale is reintegrated in France, despite maintaining overtones that will forever be considered American.

16. Pierre Bayard, Qui a tué Roger Ackroyd? (Paris: Minuit, 1998), p. 110.

17. As Ross Chambers reminds us in Loiterature, the word 'trivial' comes from the Latin term for the intersection of three ways (p. 7).

\section{Romance Studies, 27 133-144 (2009)}

Alistair Rolls, School of Humanities and Social Science, University of Newcastle, Callaghan, NSW 2308, Australia. Email: Alistair.Rolls@newcastle.edu.au 